\title{
Faktore by die oorweging van kredietverlening in verbruikersbankwese
}

\author{
P.L.S. Ackermann \\ Skool vir Bedryfsleiding, Universiteit van Suid-Afrika, Pretoria \\ W.P.J. van Rensburg \\ Departement van Bedryfsekonomie, Universiteit van Suid-Afrika, Pretoria
}

\begin{abstract}
Factors in considering the granting of credit in consumer banking. In this study the authors attempt to identify underlying factors from various evaluation criteria (as observed by bank managers) in considering the granting of credit in consumer banking with regard to the various race groups of the Republic of South Africa. The sample consists of 510 managers from the consumer division of general and commercial banks. With the aid of principal factor analysis six underlying factors are identified with respect to Indians, whereas five underlying factors are identified with regard to coloureds, whites and blacks. S. Afr. J. Bus. Mgmt. 1985, 16: $185-194$
\end{abstract}

In hierdie ondersoek word gepoog om, by die oorweging van kredietverlening in verbruikersbankwese, uit verskeie keuringskriteria onderliggende dimensies of faktore te identifiseer, gegrond op bestuurders se persepsie van die relatiewe belangrikheid van die keuringskriteria met betrekking tot die onderskeie rassegroepe in die Republiek van Suid-Afrika. Die steekproef bestaan uit 510 bestuurders in die verbruikersafdeling van algemene- en handelsbanke. By Indiërs word daar met behulp van hooffaktorontleding ses onderliggende faktore geidentifiseer, tenwyl by kleurlinge, blankes en swartes elk vyf onderliggende faktore geïdentifiseer word.

S.Afr. Tydskr. Bedryfsl. 1985, 16: 185-194

P.L.S. Ackermann ${ }^{\star}$

Skool vir Bedryfsleiding, Universiteit van Suid-Afrika, Posbus 392, Pretoria, 0001 Republiek van Suid-Afrika

\section{W.P.J. van Rensburg}

Departement Bedryfsekonomie, Universiteit van Suid-Afrika, Posbus 392, Pretoria, 0001 Republiek van Suid-Afrika

*Aan wie korrespondensie gerig moet word

\section{Inleiding}

Die voorspelling van kredietrisiko's ter bekamping van onverhaalbare skulde het gedurende die afgelope aantal jare toenemend belangrik geword. Voorspelling met behulp van numeriese puntetoekenningstelsels is gaandeweg met meer wetenskaplike voorspellingsmodelle vervang. Verskeie ondersoeke, byvoorbeeld dié deur Pinches \& Mingo (1973), Sexton (1977), Tabor \& Bowers (1977), Winginton (1980) en Van Rensburg (1983) het as uitgangspunt gehad om kredietrisiko's reeds in die aansoekstadium te probeer voorspel. Die soektog na voorspellers van kredieterisiko's duur steeds voort, hoofsaaklik omdat die verklaarde variansie van kredietrisiko in baie van die ondersoeke te laag is om die voorspellingsmodelle in die praktyk sinvol te kan gebruik.

In die Republiek van Suid-Afrika styg die lewenspeil van veral die kleurlinge, swartes en Indiërs vinnig. Die verwagte groter vraag na finansiële dienste deur laasgenoemde drie rassegroepe', sal veral die bankinstellings binne die finansiële diensindustrie onder toenemende druk plaas. Met die verwagte toetrede van meer rassegroepe tot die gebied van kredietverlening deur bankinstellings, bouverenigings en ander finansiële instellings, behoort die kredietevalueringsproses, of keuring soos dit ook bekend staan, ook meer aandag te geniet. Verbruikersbankbestuurders was tradisioneel bekend met die blanke as kredietverbruiker, maar die vraag ontstaan nou of die evaluering van kredietaansoeke vir kleurlinge, Indiërs en swartes volgens dieselfde norme beoordeel kan word, al dan nie. Bankbestuurders sal in die toekoms toenemend gekonfronteer word met allerlei kredietaansoeke. Hoe hierdie ander rassegroepe se aansoeke geinterpreteer gaan word, is tans nog nie bekend nie en wetenskaplike ondersoeke om antwoorde hierop te vind, sowel as kredietrisikovoorspellings by kleurlinge, Indiërs en swartes sal in die nabye toekoms 'n dringende behoefte word. Bankbestuurders se persepsie van die kredietevalueringskriteria met betrekking tot die ander rassegroepe, sal moontlik antwoorde kan verskaf wat in die toekoms as riglyne sal kan dien.

\section{Doel en omvang van die ondersoek}

Die doel van hierdie ondersoek is om, by die oorweging van kredietverlening aan 'n individu, uit verskeie keuringskriteria onderliggende dimensies of faktore te identifiseer, gegrond op bestuurders se persepsie van die relatiewe belangrikheid van die keuringskriteria met betrekking tot die onderskeie rassegroepe in die Republiek van Suid-Afrika.

Die ondersoek is beperk tot handels- en algemene banke, die grootste voorsieners van verbruikerskrediet in die vorm van afbetalingsverkooptransaksies en huurtransaksies. 
(Vergelyk die kumulatiewe groei in bates van handels- en algemene banke met die kumulatiewe groei in afbetalingsverkooptransaksies en huurtransaksies soos in Tabelle 1 en 2 aangetoon.)

Die insluiting van Indiërs, kleurlinge, blankes en swartes as grootste deel van die Suid-Afrikaanse bevolkingsamestelling is gedoen om die resultate en moontlike afleidings uit die ondersoek so omvattend en verteenwoordigend as moontlik van die totale bevolkingsamestelling te kry. Veral in die lig van die snelgroeiende koopkrag en welvarendheid van die Indiërs, kleurlinge en swartes in die Suid-Afrikaanse gemeenskap, is dit vanselfsprekend dat dié groep ook by ' $n$ ondersoek van hierdie aard ingesluit behoort te word.

\section{Kriteria by kredietevaluering aanwesig}

Die Tweede Wêreldoorlog (1939-1945) is gekenmerk deur 'n skerp daling in verbnuikerskrediet as gevolg van die skaarste aan verbruikersgoedere gedurende die oorlogsjare. $\mathrm{Na}$ die oorlog het aktiwiteite weer sterk begin toeneem en verdubbel tot rekordvlakke. Verbruikerskrediet het ontwikkel in 'n leefwyse, iets wat deel geword het van bykans elke huis. houding - ' $n$ algemeen aanvaarde manier om veral duursame verbruikersartikels te bekom. Veral paaiementsfinansiering (afbetalingsverkooptransaksies en huurtransaksies) het by verbruikers in gewildheid toegeneem. In die Republiek van Suid-Afrika was die groei in laasgenoemde twee soorte verbruikerskrediet volgens die Kwartaalverslag van die SuidAfrikaanse Reserwebank, Maart 1985, gedurende die afgelope dekade bykans $1800 \%$ (Tabel 2).

Beckman \& Bartels (1955) was reeds in 1924 (eerste uitgawe) van mening dat kredietevaluering rondom die sogenaamde vier C's sentreer, naamlik 'character, capacity, capital and collateral'. Sinkey (1983:39) deel steeds hierdie mening, maar met die toevoeging van ' $\mathrm{n}$ vylde $\mathrm{C}$, naamlik 'conditions'. Die toevoeging van ' $n$ vyfde $C$ word veral deur kredietbestuurders uit die finansiële sektore van die ekonomie as 'n noodsaaklikheid beskou. Cole (1982:301) stel dit dat slegs vrae rakende die historiese agtergrond van die kliënt van belang is.

Tabel 1 Totale bates en kumulatiewe groei in bates van handels- en algemene banke in die finansiële diensindustrie in die Republiek van Suid. Afrika vanaf 31 Desember 1973 tot 31 Desember 1984 ( $R$, miljoen)

\begin{tabular}{|c|c|c|c|c|c|c|}
\hline $\begin{array}{c}\text { Jaar } \\
\text { eindigend }\end{array}$ & $\begin{array}{c}\text { Handels- } \\
\text { banke }\end{array}$ & $\begin{array}{l}\text { Kumulatiewe } \\
\text { groei: } \\
\text { handels- } \\
\text { banke: } 1973 \\
=100\end{array}$ & $\begin{array}{c}\text { Algemene } \\
\text { banke }\end{array}$ & $\begin{array}{l}\text { Kumulatiewe } \\
\text { groei: } \\
\text { algemene } \\
\text { banke: } 1973 \\
=100\end{array}$ & Totaal & $\begin{array}{l}\text { Kumulatiewe } \\
\text { groei: totaal } \\
\text { van handels- } \\
\text { en atgemene } \\
\text { banke: } 1973 \\
=100\end{array}$ \\
\hline 1973 & 5740 & 100 & 2480 & 100 & 8220 & 100 \\
\hline 1974 & 6823 & 118,9 & 2771 & 111,7 & 9594 & 116,7 \\
\hline 1975 & 8130 & 141,6 & 3461 & 139,6 & 11591 & 141,0 \\
\hline 1976 & 9119 & 158,9 & 3897 & 157,1 & 13016 & 158,3 \\
\hline 1977 & 9795 & 170,6 & 4094 & 165,1 & 13889 & 169,0 \\
\hline 1978 & 11139 & 194,1 & 4770 & 192,3 & 15909 & 193.5 \\
\hline 1979 & 13368 & 232,9 & 5518 & 222,5 & 18886 & 229,8 \\
\hline 1980 & 15832 & 275,8 & 8000 & 322,6 & 23832 & 289,9 \\
\hline 1981 & 19487 & 339,5 & 11616 & 468,4 & 31103 & 378,4 \\
\hline 1982 & 26092 & 454,6 & 10704 & 431,6 & 36796 & 447,6 \\
\hline 1983 & 30376 & 529,2 & 12561 & 506,5 & 42937 & 522,3 \\
\hline 1984 & 39767 & 692,8 & 15494 & 624,8 & 55261 & 672,3 \\
\hline
\end{tabular}

(Saamgestel uit: Suid-Afrikaanse Reserwebank: Kwartaalverslae Maart 1980 tot Maart 1985)

Tabel 2 Totale bates in die vorm van afbetalingsverkooptransaksies en huurtransaksies van handelsbanke en algemene banke in die finansiële diensindustrie in die Republiek van Suid-Afrika vanaf 31 Desember 1973 tot 31 Desember 1984 ( $R$, miljoen)

\begin{tabular}{ccccccc}
\hline $\begin{array}{c}\text { Jaar } \\
\text { eindigend }\end{array}$ & $\begin{array}{c}\text { Handels- } \\
\text { bank }\end{array}$ & $\begin{array}{c}\text { Kumulatiewe } \\
\text { groei (jaar } \\
1973 \text { as } \\
100 \text { geneem) }\end{array}$ & $\begin{array}{c}\text { Algemene } \\
\text { bank }\end{array}$ & $\begin{array}{c}\text { Kumulatiewe } \\
\text { groei (jaar } \\
1973 \text { as } \\
100 \text { geneem) }\end{array}$ & $\begin{array}{c}\text { Totaal } \\
\text { Kumulatiewe } \\
\text { groei (jaar } \\
1973 \text { as 100 } \\
\text { geneem }\end{array}$ \\
\hline 1973 & 69 & 100 & 763 & 100 & 832 & 100 \\
1974 & 138 & 200,0 & 793 & 103,9 & 931 & 111,9 \\
1975 & 231 & 334,8 & 1143 & 149,8 & 1374 & 165,1 \\
1976 & 252 & 365,2 & 1444 & 189,2 & 1696 & 203,8 \\
1977 & 289 & 418,8 & 1557 & 204,1 & 1848 & 204,1 \\
1978 & 415 & 601,4 & 2120 & 277,9 & 2535 & 304,7 \\
1979 & 557 & 897,2 & 2780 & 364,4 & 3337 & 401,1 \\
1980 & 682 & 988,4 & 4348 & 569,9 & 5030 & 604,6 \\
1981 & 1145 & 1659,4 & 6491 & 850,7 & 7637 & 917,8 \\
1982 & 2989 & 4331,9 & 6684 & 876,0 & 9673 & 1161,6 \\
1983 & 3972 & 5756,5 & 8067 & 1057,3 & 12039 & 1446,9 \\
1984 & 5743 & 8323,2 & 10034 & 1315,1 & 15777 & 1896,3 \\
\hline
\end{tabular}

(Saamgestel uit: Suid-Afrikaanse Reserwebank: Kwartaalverslae Maart 1980 tot Maart 1985) 
Tweedens behoort slegs vrae wat op voorspellingsmoontlikhede dui aan die kliënt gestel te word, naamlik wat die kliënt se huidige situasie is. Die interpretasie en uiteindelike besluitneming in terme van die voorgelegde inligting is ' $n$ moeilike taak. Cole se standpunt met betrekking tot die probleem van fisiese besluitneming word soos volg gestel (p.301): 'Making these decisions is the single most important credit activity; all other activities of the credit department are contributory to this function'.

Die volgende vrae in verband met die kliënt se kredietwaardigheid is volgens Cole van kernbelang:

- besonderhede van vorige betaalrekord(s) (historiese agtergrond);

- inkomste (voorspellingskriterium);

- werkgewer en beroep (voorspellingskriterium);

- tydperk en plek woonagtig (historiese agtergrond);

- huwelikstatus (historiese agtergrond);

- ouderdom (historiese agtergrond);

- kredietverwysings (historiese agtergrond);

- reserwes, bates (voorspellingskriterium);

- surplus batewaarde in artikel (voorspellingskriterium); en

- sekuriteit (voorspellingskriterium).

Sedert die baanbrekerswerk van Beckman \& Bartels (1955) tot die meer resente benaderings van Cole (1982) en Sinkey (1983) het verskeie ander navorsers oor die evalueringsproses navorsing gedoen, waaronder Boggess (1967), Wantland (1977), Eisenbeis (1980), Zimmer (1981) en Van Rensburg (1983) die belangrikste bydrae gelewer het.

'n Balans tussen 'n liberale en konserwatiewe evaluering is nodig. Boggess (1967) beveel 'n rekenaarondersteunde prosedure aan om die meriete van kredietaansoekers met behulp van 'n ontleding van kliënte se persoonlike eienskappe te weeg. ' $n$ 'Credit-scoring'-metode vir optimale keuring van swak risiko's word voorgestel. Deur die toepassing van 'n statistiese tegniek, soos byvoorbeeld meervoudige diskriminantontleding, word die relatiewe belangrikheid van elke kriteruim bepaal. 'n Kredietkeuringsvergelyking bekend as 'n 'creditscoring model' word saamgestel. Gewigte word met behulp van dié vergelyking bereken. Die metode van gewigtetoekenning aan verskillende keuringskriteria deur gebruikmaking van meervoudige regressie-ontleding of meervoudige diskriminantontleding het sedert Boggess se ondersoek in 1967 baie in gewildheid toegeneem. Verskeie navorsers, byvoorbeeld Stanhouse \& Sherman (1979), Rothenberg (1980), Grablowsky (1981) en Van Rensburg (1983) het onder meer ondersoeke gedoen waarin van soortgelyke statistiese tegnieke gebruik gemaak is. Baie van hierdie ondersoeke is gekritiseer omdat die proporsie variansie van kredietrisiko verklaar baie laag was en die modelle dus nie 'n groot bydrae kon lewer om die kredietevalueringstaak van bestuurders te vergemaklik nie.

Dickson (1981) het ondersoek ingestel na die invloed en houdings jeens die begrip risiko in finansiële besluitnemings wat die voorspelling van risiko ingesluit het. Van die vroeëre navorsers op dié terrein was, onder andere, Grayson (1960) en Spetzler (1968), terwyl Handa (1977) en Karmarker (1978) van die meer resente navorsingstukke die lig laat sien het. Al die ondersoeke was egter gerig op spekulatiewe risikobesluitneming - dit is besluite wat byvoorbeeld die moontlikheid van of 'n wins of 'n verlies ingehou het.

Die mening word gehuldig dat kredietrisiko en kredietrisikovoorspellings nie eensydig spekulatief van aard kan wees nie en daarom kan besluitnemings met betrekking tot die aanvaarding, al dan nie, ook nie as spekulatiewe besluitneming beskou word nie. 'n Bestuurder se doel wanneer hy 'n aansoek om krediet evalueer en dit aanvaar, is om 'n wins uit die transaksie te realiseer en nie om 'n verlies te toon nie. Kredietbes/uite is dus positiewe besluite. Geen ondersoeke kon gevind word waarin die persepsie van bestuurders bepaal is jeens risiko in besluitnemings wat dui op 'n verliesvooruitsig as sulks nie. Daar was wel besluitnemings ter voorkoming van verliese, dit wil sê besluite om winste te beskerm of te verstewig.

Tabor \& Bowers (1977) het in hul ondersoek probeer om die veranderlikes wat gebruik word in die kredietevaluering van lae-inkomste-verbruikers te identifiseer. Ten einde krediet te kan bekom moet 'n verbruiker oor sekere eienskappe beskik wat die lener sal oortuig dat die aansoeker sy skuld sal betaal. In die Tabor \& Bowers ondersoek is 800 rekenings van laeinkomste-verbruikers met behulp van meervoudige regressieontleding gebruik om 'n kredietevalueringsmodel saam te stel. Die model het geblyk nie geskik te wees om goeie en swak risiko's te identifiseer nie. Onafhanklike veranderlikes wat normaalweg by die hoër inkomstegroep in die vergelyking ingesluit is, soos byvoorbeeld besit van 'n telefoon, besit van 'n bankrekening en tydperk werksaam by huidige werkgewer, is nie geselekteer in die voorspellingsmodel van laeinkomstegroepe nie. Andersom is ander onafhanklike veranderlikes soos salarisaftrekkings, ouderdom, huwelikstatus en aanwesigheid van 'n verband geselekteer, wat nie by hoërinkomstegroepe die geval was nie.

Die ondersoek van Tabor \& Bowers het beslis die vraag of hoë- en lae-inkomstegroepe oor dieselfde kam geskeer moet word wanneer dit by kredietevaluering en die gebruikmaking van kredietevalueringsmodelle kom, uitgelig.

\section{Probleemstelling}

Die probleem van hierdie ondersoek het betrekking op die vraag of daar onderliggend aan die groot getal keuringskriteria 'n kleiner getal dimensies of faktore geïdentifiseer kan word, gegrond op bankbestuurders se persepsie van die relatiewe belangrikheid van die keuringskriteria.

\section{Navorsingsontwerp en -ontleding}

Die steekproef het bestaan uit 510 bestuurders in die verbruikersafdeling van die algemene- en handelsbanke. Die geografiese verspreiding van die bestuurders word in Tabel 3 aangetoon. Die bestuurders wat aan die steekproef deelgeneem het, was almal vir ten minste een jaar 'n bankbestuurder met dieselfde of langer ondervinding van kredietevaluering. Die persentasie bestuurders met min ondervinding van kredietevaluering was egter aansienlik minder as die bestuurders met jarelange ondervinding. Die gemiddelde tydperk werksaam as

Tabel 3 Geografiese verspreiding van bestuurderssteekproef oor die Republiek van Suid-Afrika

\begin{tabular}{lcc}
\hline Gebied & $\begin{array}{c}\text { Aantal } \\
\text { bestuurders }\end{array}$ & Persentasie \\
\hline Pretoria/Johannesburg & 158 & 30,98 \\
Vereeniging en Vaaldriehoek & 31 & 6,08 \\
Durban/Pietermaritzburg en & & \\
$\quad$ omliggende gebiede & 36 & 7,06 \\
Kaapstad/Bellville en omgewing & 45 & 8,02 \\
Port Elizabeth en omgewing & 26 & 5,10 \\
Bloemfontein/Welkom & 15 & 2,94 \\
Transvaalse plattelandse gebiede & 112 & 21,96 \\
Natalse plattelandse gebiede & 23 & 4,51 \\
Kaapse plattelandse gebiede & 42 & 8,24 \\
Vrystaatse plattelandse gebiede & 22 & 4,31 \\
Totaal & 510 & 100 \\
\hline
\end{tabular}


bestuurders en gemiddelde tydperk van ondervinding van kredietevaluering, word tesame met sekere persoonlike besonderhede in Tabel 4 verskaf.

Die vraelys het bestaan uit 22 keuringskriteria. Ten einde die inhoudsgeldigheid van die vraelys te verhoog, is met die hulp van bankbestuurs gepoog om die evalueringskriteria verteenwoordigend van al daardie kriteria wat normaalweg by die evalueringsproses aanwesig is, te maak. Die keurings-

Tabel 4 Persoonlike besondehede van bankbestuurders wat by bestuurderssteekproef ingesluit is

\begin{tabular}{|c|c|c|c|}
\hline $\begin{array}{l}\text { Item } \\
\mathrm{Nr}\end{array}$ & $\begin{array}{l}\text { Persoonlike besonderhede } \\
\text { van bestuurders }\end{array}$ & Aantal & $\begin{array}{c}\text { Persentasie/ } \\
\text { Standaard } \\
\text { afwyking* }\end{array}$ \\
\hline 1 & Stedelike gebied werksaam & 311 & 60,98 \\
\hline 2 & Plattelandse gebied werksaam & 199 & 39,02 \\
\hline 3 & Huistaal Afrikaans & 432 & 84,71 \\
\hline 4 & Huistaal Engels & 78 & 15,29 \\
\hline 5 & $\begin{array}{l}\text { Hoogste opvoedkundige } \\
\text { kwalifikasies }\end{array}$ & & \\
\hline 5.1 & Standerd agt & 15 & 2,94 \\
\hline 5.2 & Standerd tien & 396 & 77,65 \\
\hline 5.3 & Diploma kursus & 59 & 11,57 \\
\hline 5.4 & B-graad & 34 & 6,67 \\
\hline 5.5 & Honneursgraad & 5 & 1,00 \\
\hline 5.6 & M-graad & 1 & 0,17 \\
\hline 6 & $\begin{array}{l}\text { Gemiddelde tydperk as } \\
\text { bestuurder werksaam }\end{array}$ & 6,53 jaar & $5,8865^{*}$ \\
\hline 7 & $\begin{array}{l}\text { Gemiddelde tydperk as kre- } \\
\text { dietevalueringsamptenaar } \\
\text { werksaam }\end{array}$ & 10,09 jaar & $6,7018^{*}$ \\
\hline 8 & $\begin{array}{l}\text { Gemiddelde bruto inkomste } \\
\text { per jaar }\end{array}$ & R24 340 & R1 903* \\
\hline 9 & $\begin{array}{l}\text { Gemiddelde ouderdom } \\
\text { van bestuurders }\end{array}$ & 41,21 jaar & $8,2494^{*}$ \\
\hline
\end{tabular}

kriteria in die vraelys ingesluit, was die volgende: bruto inkomste; besit van lewens en/of uitkeerversekering; huwelikstatus; aantal afhanklikes; tydperk woonagtig by huidige adres; beroep; ouderdom van artikel gefinansier; afbetalingstussenposes; binne- en buiteverwysings; besit van bankrekening; bestaande of nuwe kliënt; besit van vaste eiendom; besit van telefoon by woonadres; ouderdom van aansoeker; afbetalingstermyn; vonnisse teen kredietrekord; géslag; tydperk werksaam by vorige werkgewer; gebied woonagtig; totale uitgawes; tydperk werksaam by huidige werkgewer; taal.

Die 22 evalueringskriteria word gekodeer deur responsies op elke kriterium op 'n vyfpuntskaal van 1 tot 5 aan te slaan. Indien 'n kriterium deur 'n respondent as onbelangrik beskou word, word daar aan die responsie 'n telling van 1 toegeken. Indien 'n kriterium deur 'n respondent as uiters belangrik beskou word, word daar aan dié responsie 'n 5 toegeken. Die evalueringskriteria is dus skaalwaardes van links na regs toegeken, waar die waarde van die posisie verste regs, 'n 5 toegeken word en die posisie verste links 'n 1 .

Om uit die keuringskriteria onderliggende faktore te bepaal, is daar van 'n hooffaktorontleding met die meegaande 'varimax'-rotasie gebruik gemaak. Die rekenaarprogram wat gebruik is, is die hooffaktoronledingsprogram BMDP (BMDP4M). Kaiser (1960) se kriterium vir die getal faktore wat geidentifiseer is, is gebruik.

\section{Resultate en interpretasie}

In Tabel 5 word die gemiddeldes en standaardafwykings van die keuringskriteria ten opsigte van die rassegroepe afsonderlik asook gesamentlik weergegee.

Die geroteerde faktormatrikse en verspreiding van kommunaliteite vir keuringskriteria soos met betrekking tot die verskillende rassegroepe bepaal, verskyn in Tabelle 6, 7, 8 en 9 . Die proporsie variansie by elke geval verklaar, word onderaan elk van die betrokke tabelle aangetoon.

Tabel 5 Gemiddeldes $(\bar{X})$ en standaardafwykings (S) van keuringskriteria ten opsigte van bestuurderssteekproef vir rassegroepe afsonderlik en gesamentlik

\begin{tabular}{|c|c|c|c|c|c|c|c|c|c|c|c|}
\hline \multirow{2}{*}{$\begin{array}{l}\text { Keurings- } \\
\text { kriterium } \\
\text { nommer }\end{array}$} & \multirow{2}{*}{ Beskrywing van keuringskriterum } & \multicolumn{2}{|c|}{ Kleurlinge } & \multicolumn{2}{|c|}{ Indiërs } & \multicolumn{2}{|c|}{ Blankes } & \multicolumn{2}{|c|}{ Swartes } & \multicolumn{2}{|c|}{ Alle groepe } \\
\hline & & $\not X$ & $s$ & $\bar{X}$ & $s$ & $\bar{X}$ & $s$ & 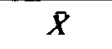 & $s$ & $\bar{X}$ & $s$ \\
\hline 1 & Bruto inkomste van kliënt & 4,65294 & 0,65679 & 4,59020 & 0,71656 & 4,33725 & 0,82922 & 4,70356 & 0,71412 & 4,57073 & 0,74478 \\
\hline 2 & $\begin{array}{l}\text { Aanwesigheid van lewens- en/of } \\
\text { uitkeerversekering }\end{array}$ & 3,09804 & 1,30820 & 3,07647 & 1,30438 & 3,03529 & 1,13989 & 2,96640 & 1,44498 & 3,04420 & 1,30356 \\
\hline 3 & Huwelikstatus & 2,90196 & 1,22442 & 2,81373 & 1,21169 & 2,76667 & 1,15518 & 2,61462 & 1,33487 & 2,77456 & 1,23653 \\
\hline 4 & Aantal afhanklikes & 3,57059 & 1,20164 & 3,39804 & 1,20591 & 3,16471 & 1,13019 & 3,46245 & 1,34517 & 3,39882 & 1,23108 \\
\hline 5 & $\begin{array}{l}\text { Tydperk woonagtig by huidige } \\
\text { adres }\end{array}$ & 4,24510 & 0,88244 & 4,20196 & 0,88892 & 3,75098 & 0,98851 & 4,24901 & 0,99765 & 4,11149 & 0,96313 \\
\hline 6 & Beroep & 4,12353 & 0,96217 & 4,05294 & 0,99069 & 3,80196 & 0,94339 & 4,20553 & 1,04609 & 4,04568 & 0,99699 \\
\hline 7 & Ouderom van artikel & 4,39804 & 0,78567 & 4,33529 & 0,82883 & 3,87255 & 0,97585 & 4,50988 & 0,77389 & 4,27849 & 0,87866 \\
\hline 8 & Afbetalingstussenposes & 4,25490 & 1,01740 & 4,19020 & 1,05874 & 3,61373 & 1,09015 & 4,33399 & 1,01333 & 4,09774 & 1,08271 \\
\hline 9 & Kredietverwysings & 4,45294 & 0,87350 & 4,47255 & 0,86983 & 4,12549 & 0,94855 & 4,52372 & 0,85390 & 4,39342 & 0,90042 \\
\hline 10 & Besit van bankrekening & 3,63529 & 1,10025 & 3,66863 & 1,07389 & 3,53725 & 1,00372 & 3,62451 & 1,20120 & 3,61640 & 1,09711 \\
\hline 11 & Bestaande of nuwe kliënt & 4,05490 & 1,03235 & 4,07843 & 1,02317 & 3,45882 & 1,10423 & 4,14625 & 1,05978 & 3,93418 & 1,09031 \\
\hline 12 & Besit van vaste eiendom & 3,83137 & 1,21831 & 3,98235 & 1,15994 & 3,73922 & 1,09859 & 3,53162 & 1,48790 & 3,77161 & 1,25923 \\
\hline 13 & Besit van telefoon by woonadres & 2,97647 & 1,34859 & 3,04510 & 1,34147 & 2,89412 & 1,24762 & 2,86166 & 1,44901 & 2,94450 & 1,34926 \\
\hline 14 & Ouderom van kliënt & 3,68431 & 0,98133 & 3,65294 & 1,00838 & 3,31961 & 0,99597 & 3,73518 & 1,04788 & 3,59774 & 1,02104 \\
\hline 15 & Afbetalingstermyn & 3,81569 & 1,06809 & 3,76863 & 1,06995 & 3,36471 & 1,03586 & 3,95455 & 1,10261 & 3,72544 & $1,0 \times 084$ \\
\hline 16 & Vonnisse teen kredietrekord & 4,87255 & 0,38313 & 4,87843 & 0,38758 & 4,74706 & 0,56480 & 4,86364 & 0,41647 & 4,84037 & 0,44728 \\
\hline 17 & Geslag & 3,10784 & 1,35394 & 3,02353 & 1,36164 & 2,47255 & 1,12055 & 3,37549 & 1,44377 & 2,99411 & 1,36433 \\
\hline 18 & $\begin{array}{l}\text { Tydperk werksaam by vorige } \\
\text { werkgewer }\end{array}$ & 4,00196 & 0,96195 & 3,96471 & 0,95823 & 3,59804 & 0,95539 & 4,11858 & 0,98993 & 3,92043 & 0,98518 \\
\hline 19 & Gebied woonagtig & 3,22745 & 1,27205 & 3,17451 & 1,26729 & 2,68431 & 1,18618 & 3,49012 & 1,38052 & 3,14342 & 1,30997 \\
\hline 20 & Totale uitgawe & 4,32745 & 0,92373 & 4,30196 & 0,93133 & 4,10392 & 0,98664 & 4,33202 & 0,96495 & 4,26621 & 0,95596 \\
\hline 21 & $\begin{array}{l}\text { Tydperk werksaam by huidige } \\
\text { werkgewer }\end{array}$ & 4,39020 & 0,76432 & 4,38431 & 0,77368 & 4,01961 & 0,91463 & 4,50000 & 0,76365 & 4,32318 & 0,82627 \\
\hline 22 & Taal & 1,36275 & 0,80261 & 1,38235 & 0,84384 & 1,32157 & 0,74862 & 1,55731 & 1,05571 & 1,40570 & 0,87411 \\
\hline
\end{tabular}



Tabel 6 Geroteerde faktormatriks en verspreiding van kommunaliteite $\left(h^{2}\right)$ vir keuringskriteria
volgens bestuurders vir die rassegroep kleurlinge

\begin{tabular}{|c|c|c|c|c|c|c|c|}
\hline \multirow{2}{*}{$\begin{array}{l}\text { Keurings- } \\
\text { kriterium } \\
\text { nommer }\end{array}$} & \multirow{2}{*}{ Beskrywing van keuringskriterium } & \multicolumn{5}{|c|}{ Faktore } & \multirow{2}{*}{$\begin{array}{c}\text { Kommunaliteite } \\
\left(h^{2}\right)\end{array}$} \\
\hline & & 1 & 2 & 3 & 4 & 5 & \\
\hline 1 & Bruto inkomste van kliënt & $-0,055$ & 0,184 & 0,735 & $-0,078$ & $-0,055$ & 0,586 \\
\hline 2 & $\begin{array}{l}\text { Aanwesigheid van lewens- en/of- } \\
\text { uitkeerversekering }\end{array}$ & 0,091 & $-0,225$ & 0,361 & 0,588 & 0,342 & 0,652 \\
\hline 3 & Huwelikstatus & 0,127 & 0,537 & 0,085 & $-0,091$ & 0,342 & 0,437 \\
\hline 4 & Aantal afhanklikes & 0,056 & 0,605 & 0,314 & 0,021 & 0,061 & 0,472 \\
\hline 5 & Tydperk woonagtig by huidige & & & & & & \\
\hline & adres & 0,427 & 0,486 & 0,149 & 0,158 & $-0,165$ & 0,493 \\
\hline 6 & Beroep & 0,439 & 0,341 & 0,254 & 0,156 & 0,071 & 0,403 \\
\hline 7 & Ouderdom van artikel & 0,591 & 0,186 & 0,102 & 0,110 & $-0,200$ & 0,446 \\
\hline 8 & Afbetalingstussenposes & 0,738 & 0,013 & 0,147 & $-0,019$ & 0,136 & 0,585 \\
\hline 9 & Kredietverwysings & 0,278 & $-0,005$ & 0,555 & 0,112 & 0,100 & 0,408 \\
\hline 10 & Besit van bankrekening & 0,235 & $-0,010$ & 0,022 & 0,740 & 0,038 & 0,605 \\
\hline 11 & Bestaande of nuwe kliënt & 0,479 & 0,154 & 0,139 & 0,366 & $-0,020$ & 0,407 \\
\hline 12 & Besit van vaste eiendom & $-0,021$ & 0,376 & 0,072 & 0,688 & $-0,074$ & 0,626 \\
\hline 13 & Besit van telefoon by woonadres & 0,102 & 0,657 & $-0,136$ & 0,270 & 0,111 & 0,546 \\
\hline 14 & Ouderdom van kliënt & 0.410 & 0,607 & 0,110 & 0,035 & $-0,035$ & 0,551 \\
\hline 15 & Afbetalingstermyn & 0,693 & 0,167 & 0,081 & 0,205 & 0,137 & 0,575 \\
\hline 16 & Vonnisse teen kredietrekord & 0,315 & $-0,013$ & 0,552 & 0,125 & $-0,236$ & 0,475 \\
\hline 17 & Geslag & 0,559 & 0,297 & 0,122 & $-0,121$ & 0,406 & 0,595 \\
\hline 18 & $\begin{array}{l}\text { Tydperk werksaam by vorige } \\
\text { werkgewer }\end{array}$ & 0,368 & 0,217 & 0,344 & 0,351 & 0,091 & 0,432 \\
\hline 19 & Gebied woonagtig & 0,271 & 0,540 & 0,058 & 0,038 & 0,355 & 0,496 \\
\hline 20 & Totale uitgawes & 0,238 & 0,165 & 0,483 & 0,269 & 0,077 & 0,395 \\
\hline 21 & $\begin{array}{l}\text { Tydperk werksaam by huidige } \\
\text { werkgewer }\end{array}$ & 0,467 & 0,294 & 0,316 & 0,236 & $-0,032$ & 0,461 \\
\hline 22 & Taal & $-0,007$ & 0,199 & $-0,081$ & 0,132 & 0,763 & 0,646 \\
\hline
\end{tabular}

Proporsie variansie verklaar $=\frac{\sum h^{2}}{\text { aantal keuringskriteria }}=\frac{11,292}{22}=0,5133$

Tabel 7 Geroteerde faktormatriks en verspreiding van kommunaliteite $\left(h^{2}\right)$ vir keuringskriteria volgens bestuurders vir die rassegroep Indiërs

\begin{tabular}{|c|c|c|c|c|c|c|c|c|}
\hline \multirow{2}{*}{$\begin{array}{l}\text { Keurings- } \\
\text { kriterium } \\
\text { nommer }\end{array}$} & \multirow{2}{*}{ Beskrywing van keuringskriterium } & \multicolumn{6}{|c|}{ Faktore } & \multirow{2}{*}{$\underset{\left(h^{2}\right)}{\text { Kommunaliteite }}$} \\
\hline & & 1 & 2 & 3 & 4 & 5 & 6 & \\
\hline 1 & Bruto inkomste van kliënt & 0,067 & $-0,014$ & $-0,031$ & 0,281 & 0,138 & 0,729 & 0,635 \\
\hline 2 & $\begin{array}{l}\text { Aanwesigheid van lewens- en/of } \\
\text { uitkeerversekering }\end{array}$ & 0,103 & $-0,018$ & 0,011 & 0,157 & 0,811 & 0,079 & 0,670 \\
\hline 3 & Huwelikstatus & 0,140 & 0,623 & 0,063 & $-0,011$ & $-0,020$ & 0,158 & 0,437 \\
\hline 4 & Aantal afhanklikes & 0,004 & 0,488 & 0,186 & 0,043 & $-0,042$ & 0,513 & 0,540 \\
\hline 5 & $\begin{array}{l}\text { Tydperk woonagtig by huidige } \\
\text { adres }\end{array}$ & 0,193 & 0,256 & 0,546 & 0,240 & $-0,114$ & 0,206 & 0,514 \\
\hline 6 & Beroep & 0,354 & 0,273 & 0,289 & 0,205 & 0,078 & 0,255 & 0,397 \\
\hline 7 & Ouderdom van artikel & 0,615 & $-0,049$ & 0,212 & $-0,067$ & 0,115 & 0,453 & 0,648 \\
\hline 8 & Afbetalingstussenposes & 0,735 & 0,114 & $-0,051$ & 0,237 & 0,111 & 0,064 & 0,628 \\
\hline 9 & Kredietverwysings & 0,073 & 0,120 & $-0,005$ & 0,776 & 0,106 & 0,102 & 0,644 \\
\hline 10 & Besit van bankrekening & 0,203 & 0,043 & 0,312 & 0,025 & 0,623 & 0,085 & 0,536 \\
\hline 11 & Bestaande of nuwe kliënt & 0,386 & $-0,007$ & 0,514 & 0,232 & 0,172 & $-0,135$ & 0,515 \\
\hline 12 & Besit van vaste eiendom & $-0,044$ & 0,109 & 0,664 & $-0,038$ & 0,373 & 0,087 & 0,603 \\
\hline 13 & Besit van telefoon by woonadres & 0,037 & 0,609 & 0,370 & $-0,017$ & 0,015 & 0,038 & 0,511 \\
\hline 14 & Ouderdom van kliënt & 0,427 & 0,360 & 0,419 & 0,002 & $-0,152$ & 0,200 & 0,551 \\
\hline 15 & Afbetalingstermyn & 0,697 & 0,174 & 0,222 & 0,085 & 0,201 & $-0,032$ & 0,614 \\
\hline 16 & Vonnisse teen kredietrekord & 0,145 & $-0,139$ & 0,176 & 0,677 & $-0,013$ & 0,149 & 0,552 \\
\hline 17 & Geslag & 0,553 & 0,474 & 0,101 & 0,182 & $-0,019$ & $-0,059$ & 0,578 \\
\hline 18 & $\begin{array}{l}\text { Tydperk werksaam by vorige } \\
\text { werkgewer }\end{array}$ & 0,268 & 0,143 & 0,386 & 0,390 & 0,272 & $-0,071$ & 0,459 \\
\hline 19 & Gebied woonagtig & 0,289 & 0,635 & 0,169 & 0,122 & $-0,048$ & 0,009 & 0,533 \\
\hline 20 & Totale uitgawes & 0,079 & 0,101 & 0,329 & 0,377 & 0,219 & 0,242 & 0,373 \\
\hline 21 & $\begin{array}{l}\text { Tydperk werksaam by huidige } \\
\text { werkgewer }\end{array}$ & 0,208 & 0,166 & 0,532 & 0,451 & 0,029 & $-0,006$ & 0,558 \\
\hline 22 & Taal & $-0,023$ & 0,647 & $-0,164$ & 0,004 & 0,354 & $-0,175$ & 0,602 \\
\hline
\end{tabular}

Proporsie variansie verklaar $=\frac{\Sigma h^{2}}{\text { aantal keuringskriteria }}=\frac{12,098}{22}=0,5499$ 
Tabel 8 Geroteerde faktormatriks en verspreiding van kommunaliteite $\left(h^{2}\right)$ vir keuringskriteria volgens bestuurders vir die rassegroep blankes

\begin{tabular}{|c|c|c|c|c|c|c|c|}
\hline \multirow{2}{*}{$\begin{array}{l}\text { Keurings- } \\
\text { kriterium } \\
\text { nommer }\end{array}$} & \multirow[b]{2}{*}{ Beskrywing van keuringskriterium } & \multicolumn{5}{|c|}{ Faktore } & \multirow{2}{*}{$\begin{array}{l}\text { Kommunaliteite } \\
\qquad\left(h^{2}\right)\end{array}$} \\
\hline & & 1 & 2 & 3 & 4 & 5 & \\
\hline 1 & Bruto inkomste van kliënt & $-0,000$ & 0,136 & $-0,072$ & 0,632 & $-0,141$ & 0,443 \\
\hline 2 & $\begin{array}{l}\text { Aanwesigheid van lewens- en/of } \\
\text { uitkeerversekering }\end{array}$ & 0,059 & 0,037 & 0,093 & 0,132 & 0,776 & 0,633 \\
\hline 3 & Huwelikstatus & 0,654 & 0,081 & 0,109 & 0,011 & $-0,001$ & 0,446 \\
\hline 4 & Aantal afhanklikes & 0,591 & 0,050 & $-0,059$ & 0,340 & 0,015 & 0,471 \\
\hline 5 & $\begin{array}{l}\text { Tydperk woonagtig by huidige } \\
\text { adres }\end{array}$ & 0,415 & 0,183 & 0,418 & 0,255 & $-0,314$ & 0,544 \\
\hline 6 & Beroep & 0,235 & 0,400 & 0,299 & 0,168 & $-0,014$ & 0,333 \\
\hline 7 & Ouderdom van artikel & $-0,069$ & 0,520 & 0,342 & 0,203 & $-0,128$ & 0,450 \\
\hline 8 & Afbetalingstussenposes & 0,145 & 0,699 & $-0,054$ & 0,043 & $-0,025$ & 0,515 \\
\hline 9 & Kredietverwysings & 0,232 & 0,053 & 0,217 & 0,548 & 0,109 & 0,416 \\
\hline 10 & Besit van bankrekening & 0,073 & 0,030 & 0,624 & $-0,013$ & 0,433 & 0,578 \\
\hline 11 & Bestaande of nuwe kliënt & 0,013 & 0,256 & 0,654 & $-0,022$ & 0,126 & 0,510 \\
\hline 12 & Besit van vaste eiendom & 0,238 & 0,065 & 0,634 & 0,120 & $-0,065$ & 0,481 \\
\hline 13 & Besit van telefoon by woonadres & 0,636 & $-0,018$ & 0,347 & 0,096 & $-0,121$ & 0,549 \\
\hline 14 & Ouderdom van kliënt & 0,398 & 0,451 & 0,195 & 0,195 & $-0,107$ & 0,449 \\
\hline 15 & Afbetalingstermyn & 0,133 & 0,734 & 0,146 & 0,066 & 0,231 & 0,635 \\
\hline 16 & Vonnisse teen kredietrekord & $-0,125$ & 0,052 & 0,365 & 0,564 & 0,078 & 0,476 \\
\hline 17 & Geslag & 0,548 & 0,360 & 0,036 & 0,000 & 0,205 & 0,473 \\
\hline 18 & $\begin{array}{l}\text { Tydperk werksaam by vorige } \\
\text { werkgewer }\end{array}$ & 0,188 & 0,399 & 0,257 & 0,190 & 0,244 & 0,356 \\
\hline 19 & Gebied woonagtig & 0,631 & 0,256 & 0,098 & $-0,020$ & 0,114 & 0,487 \\
\hline 20 & Totale uitgawes & 0,082 & 0,245 & $-0,037$ & 0,578 & 0,354 & 0,528 \\
\hline 21 & $\begin{array}{l}\text { Tydperk werksaam by huidige } \\
\text { werkgewer }\end{array}$ & 0,289 & 0,346 & 0,411 & 0,303 & $-0,059$ & 0,467 \\
\hline 22 & Taal & 0,521 & 0,079 & $-0,008$ & $-0,227$ & 0,364 & 0,462 \\
\hline
\end{tabular}

Proporsie variansie verklaar $=\frac{\sum h^{2}}{\text { aantal keuringskriteria }}=\frac{10,702}{22}=0,4865$

Tabel 9 Geroteerde faktormatriks en verspreiding van kommunaliteite $\left(h^{2}\right)$ vir keuringskriteria volgens bestuurders vir die rassegroep swartes

\begin{tabular}{|c|c|c|c|c|c|c|c|}
\hline \multirow{2}{*}{$\begin{array}{l}\text { Keurings- } \\
\text { kriterium } \\
\text { nommer }\end{array}$} & \multirow[b]{2}{*}{ Beskrywing van keuringskriterium } & \multicolumn{5}{|c|}{ Faktore } & \multirow{2}{*}{$\begin{array}{c}\text { Kommunaliteite } \\
\left(h^{2}\right)\end{array}$} \\
\hline & & 1 & 2 & 3 & 4 & 5 & \\
\hline 1 & Bruto inkomste van kliënt & 0,318 & 0,042 & $-0,006$ & $-0,281$ & 0,556 & 0,491 \\
\hline 2 & $\begin{array}{l}\text { Aanwesigheid van lewens- en/of } \\
\text { uitkeerversekering }\end{array}$ & 0,063 & 0,035 & 0,772 & $-0,046$ & 0,062 & 0,607 \\
\hline 3 & Huwelikstatus & $-0,017$ & 0,112 & 0,134 & 0,317 & 0,639 & 0,540 \\
\hline 4 & Aantal afhanklikes & 0,064 & 0,152 & 0,218 & 0,226 & 0,667 & 0,571 \\
\hline 5 & $\begin{array}{l}\text { Tydperk woonagtig by huidige } \\
\text { adres }\end{array}$ & 0,606 & 0,120 & 0,066 & 0,324 & 0,219 & 0,539 \\
\hline 6 & Beroep & 0,511 & 0,211 & 0,035 & 0,270 & 0,270 & 0,453 \\
\hline 7 & Ouderdom van artikel & 0,187 & 0,672 & 0,060 & $-0,152$ & 0,193 & 0,551 \\
\hline 8 & Afbetalingstussenposes & 0,278 & 0,671 & 0,046 & $-0,003$ & 0,080 & 0,536 \\
\hline 9 & Kredietverwysings & 0,653 & 0,096 & 0,088 & $-0,060$ & 0,037 & 0,448 \\
\hline 10 & Besit van bankrekening & 0,087 & 0,192 & 0,737 & 0,022 & 0,073 & 0,593 \\
\hline 11 & Bestaande of nuwe kliënt & 0,435 & 0,378 & 0,249 & 0,145 & $-0,217$ & 0,462 \\
\hline 12 & Besit van vaste eiendom & 0,220 & $-0,112$ & 0,624 & 0,282 & 0,169 & 0,558 \\
\hline 13 & Besit van telefoon by woonadres & 0,081 & 0,065 & 0,267 & 0,664 & 0,120 & 0,537 \\
\hline 14 & Ouderdom van kliënt & 0,238 & 0,467 & 0,007 & 0,432 & 0,100 & 0,471 \\
\hline 15 & Afbetalingstermyn & 0,129 & 0,704 & 0,273 & 0,144 & 0,015 & 0,608 \\
\hline 16 & Vonnisse teen kredietrekord & 0,596 & 0,154 & 0,103 & $-0,270$ & 0,055 & 0,465 \\
\hline 17 & Geslag & 0.122 & 0,651 & $-0,050$ & 0,336 & 0,089 & 0,562 \\
\hline 18 & $\begin{array}{l}\text { Tydperk werksaam by vorige } \\
\text { werkgewer }\end{array}$ & 0,461 & 0,260 & 0,336 & 0,227 & 0,001 & 0,466 \\
\hline 19 & Gebied woonagtig & 0,175 & 0,306 & $-0,117$ & 0,574 & 0,259 & 0,535 \\
\hline 20 & Totale uitgawes & 0,351 & 0,215 & 0,339 & 0,069 & 0,116 & 0,303 \\
\hline 21 & $\begin{array}{l}\text { Tydperk werksaam by huidige } \\
\text { werkgewer }\end{array}$ & 0,687 & 0,252 & 0,097 & 0,227 & 0,010 & 0,597 \\
\hline 22 & Taal & $-0,004$ & 0,004 & 0,040 & 0,515 & 0,005 & 0,267 \\
\hline
\end{tabular}

Proporsie variansie verklaar $=\frac{\sum h^{2}}{\text { aantal keuringskriteria }}=\frac{11,160}{22}=0,5073$ 
Faktoridentifikasie: Bestuurderspersepsie van keuringskriteria vir die onderskeie rassegroepe

Kleurlinge

Die vyf faktore wat met behulp van die hooffaktorontleding bepaal is, is geidentifiseer deur na die ladings van die keuringskriteria op elke faktor te kyk. Die sterkte van die verband tussen die onderskeie keuringskriteria en faktore word deur die grootte van die faktorladings bepaal. Slegs faktorladings van 0,30 en hoër word gewoonlik as beduidend vir identifikasiedoeleindes beskou (Sheth \& Tigert, 1970), maar weens die aanwesigheid van redelik hoë faktorladings in hierdie ondersoek, is slegs daardie keuringskriteria met ladings van 0,50 en hoër by die identifikasie van die faktore in ag geneem. Enkele keuringskriteria laai substansieel op meer as een faktor, maar dit vernietig nie die nuttigheid van sodanige kriteria by faktoridentifikasie nie.

Die vyf faktore wat geidentifiseer is, word vervolgens afsonderlik bespreek. In elke geval sal die keuringskriteria met faktorladings van 0,50 en hoër in die omskrywing van die konstruk of dimensie wat deur die betrokke keuringskriteria verteenwoordig word, gebruik word. Die nommer wat by elke faktor voor 'n keuringskriterium verskyn, is die nommer van die betrokke keuringskriterium.

\section{Faktor I: Transaksieverkenning}

Faktor I het substansiële ladings (dit wil sê, ladings van 0,50 en hoër) op vier van die 22 keuringskriteria. Die betrokke keuringskriteria is soos volg:

$\mathrm{Nr} 8$ afbetalingstussenposes 0,738

$\mathrm{Nr} 15$ afbetalingstermyn $\quad 0,693$

$\mathrm{Nr} 7$ ouderdom van artikel 0,591

$\mathrm{Nr} 17$ geslag $\quad 0,559$

Met die uitsondering van keuringskriterium $\mathrm{Nr} 1 \%$, geslag, dui die ander drie op noodsaaklike transaksieverkenningsinligting. Faktor I word dus as TRANSAKSIEVERKENNING geidentifiseer.

\section{Faktor II: Gesinsverantwoordbaarheid}

Die tweede faktor het substansiële ladings op vyf van die 22 keuringskriteria, naamlik:

$\mathrm{Nr} 13$ besit van telefoon by woonadres 0,657

$\mathrm{Nr} 14$ ouderom van kliënt $\quad 0,607$

$\mathrm{Nr} 4$ aantal afhanklikes $\quad 0,605$

$\mathrm{Nr} 19$ gebied woonagtig $\quad 0,540$

$\mathrm{Nr} 3$ huwelikstatus $\quad 0,537$

Met die moontlike uitsondering van keuringskriterium $\mathrm{Nr}$ 14, ouderdom van kliënt, dui al die ander keuringskriteria op 'n verband met die gesin en meer spesifiek die verantwoordelikheid van die kliënt met betrekking tot sy gesin en die geriewe wat hy vir sy gesin beskikbaar stel. Faktor II word gevolglik as GESINSVERANTWOORDBAARHEID geïdentifiseer.

\section{Faktor III: Finansiële- en risikogeskiedenis}

Substansiële ladings op die volgende drie keuringskriteria is by faktor III gevind:

$\mathrm{Nr} 1$ bruto inkomste van kliënt 0,735

$\mathrm{Nr} 9$ kredietverwysings $\quad 0,555$

$\mathrm{Nr} 16$ vonnisse teen kredietrekord 0,552

Hierdie keuringskriteria dui op duidelike elemente van finansiële- en risikogeneigdheid, veral wat betref die kliënt se kredietrekord. Laasgenoemde word alleenlik in sy kredietverwysings en vonnisse teen sy kredietrekord weerspieël, terwyl die bruto inkomste van die kliënt ook op risiko dui, maar meer betrekking het op die finansiële vermoë van die kliënt.
Faktor III kan gevolglik as FINANSIELLE- EN RISIKOGESKIEDENIS geidentifiseer word.

\section{Faktor IV: Sekuriteit}

Hierdie faktor het substansiële ladings op drie keuringskriteria, naamlik:

Nr 10 besit van bankrekening $\quad 0,740$

$\mathrm{Nr} 12$ besit van vaste eiendom $\quad 0,688$

$\mathrm{Nr} 2$ aanwesigheid van lewens- en/of uitkeerversekering

Beide Nrs 12 en 2, besit van vaste eiendom en aanwesigheid van lewens- en/of uitkeerversekering, het 'n direkte verbintenis met die opbou van sekuriteit deur die kliënt, terwyl $\mathrm{Nr} 10$, besit van ' $n$ bankrekening, ook ' $n$ indirekte aanduiding is dat die kliënt die moontlikheid het om sekuriteit in die vorm van 'n spaarrekening of batige lopende rekening by 'n bank of bougenootskap, op te bou. Hierdie kombinasie van keuringskriteria identifiseer Faktor IV duidelik as 'n SEKURITEITSFAKTOR.

\section{Faktor V: Patriotisme}

Die laaste faktor by kleurlinge het 'n substansiële lading op slegs een van die 22 keuringskriteria:

Nr 2 Taal

Hierdie faktor suggereer 'n faktor van PATRIOTISME maar kan nie op grond van een veranderlike uit 22 as sodanig geidentifiseer word nie.

Indiërs

Keuringskriteria met faktorladings van 0,50 en hoër is by die identifikasie van die faktore in ag geneem. Die ses faktore wat geidentifiseer is, word vervolgens afsonderlik bespreek.

\section{Faktor I: Transaksieverkenning}

Hierdie faktor het substansiële ladings op vier keuringskriteria naamlik:

$\begin{array}{ll}\mathrm{Nr} \quad 8 \text { afbetalingstussenposes } & 0,735 \\ \mathrm{Nr} 15 \text { afbetalingstermyn } & 0,697 \\ \mathrm{Nr} 7 \text { ouderdom van artikel } & 0,615 \\ \mathrm{Nr} 17 \text { geslag } & 0,553\end{array}$

Soos by kleurlinge, is dieselfde keuringskriteria by faktor I ook by Indiërs geïdentifiseer. Slegs $\mathrm{Nr} 17$ (geslag) kan nie volkome met die kern transaksie-inligting-konstruk vereenselwig word nie. Die ander drie, Nrs 8, 15 en 7, dui op noodsaaklike transaksie-inligting. Faktor I word dus as 'n TRANSAKSIEVERKENNINGSFAKTOR geïdentifiseer.

\section{Faktor II: Gesinsverantwoordbaarheid}

Die tweede faktor by Indiërs het 'n substansiële lading op vier van die 22 keuringskriteria, te wete:

$\mathrm{Nr} 2$ taal $\quad 0,647$

$\mathrm{Nr} 19$ gebied woonagtig $\quad 0,635$

$\mathrm{Nr} 3$ huwelikstatus $\quad 0,623$

$\mathrm{Nr} 13$ besit van telefoon by woonadres 0,609

Met die uitsondering van keuringskriterium $\mathrm{Nr} 22$, taal, wat op patriotisme dui (sien Faktor V by kleurlinge) dui Nrs 19, 3 en 13 op die verantwoordelikheid van die kliënt teenoor sy gesin. Faktor II word gevolglik as GESINSVERANTWOORDBAARHEID geïdentifiseer.

\section{Faktor III: Standvastigheid}

Substansiële ladings op die volgende vier keuringskriteria is by faktor III gevind:

$\mathrm{Nr} 12$ besit van vaste eiendom 
Nr 5 tydperk woonagtig by huidige adres

0,546

Nr 21 tydperk werksaam by huidige werkgewer

0,532

0,514

Nr 11 bestaande of nuwe kliënt

Keuringskriteria Nrs 12, 5 en 21 dui op die STANDVASTIGHEID van die kliënt, terwyl $\mathrm{Nr} 11$, bestaande of nuwe kliënt, ook veral in die geval van bestaande kliënte 'n aanduiding van STANDVASTIGHEID kan wees. Faktor III word as STANDVASTIGHEID geïdentifiseer.

\section{Faktor IV; Risikogeskiedenis}

Hierdie faktor het substansiële ladings op twee keuringskriteria naamlik:

$\mathrm{Nr} 9$ kredietverwysings $\quad 0,776$

Nr 16 vonnisse teen kredietrekord 0,677

Faktor IV word as RISIKOGESKIEDENIS geïdentifiseer.

\section{Faktor V: Sekuriteit}

Die vyfde faktor by Indiërs het substansiële ladings op twee van die 22 keuringskriteria, te wete:

$\mathrm{Nr} 2$ aanwesigheid van lewens- en/of uitkeerversekering $\quad 0,811$

$\mathrm{Nr} 10$ besit van bankrekening $\quad 0,623$

Wanneer daar egter na die twee keuringskriteria (Nrs 2 en

10) gesamentlik gekyk word, dui dit op die strewe van die kliënt om sy sekuriteitsposisie op te bou of te verseker. Faktor $\mathrm{V}$ word dus as 'n SEKURITEITSFAKTOR geïdentifiseer.

\section{Faktor VI: Stabiliteit}

Die laaste faktor by Indiërs het 'n substansiële lading op twee van die 22 keuringskriteria. Die betrokke keuringskriteria is die volgende:

Nr 1 bruto inkomste van kliënt 0,729

$\mathrm{Nr} 4$ aantal afhanklikes $\quad 0,514$

Alhoewel hierdie faktor oënskynlik 'n noue verband met faktor III, STANDVASTIGHEID suggereer, het dit 'n ietwat ander betekenis wat eerder dui op die finansiële weerbaarheid van die kliënt in verhouding tot sy afhanklikes. Faktor V word dus as STABILITEIT geïdentifiseer.

\section{Blankes}

Soos die geval was by die vorige twee rassegroepe, naamlik kleurlinge en Indiërs, is keuringskriteria met faktorladings van 0,50 en hoër ook hier by die identifikasie van die faktore in ag geneem. Vyf faktore is geidentifiseer en word vervolgens afsonderlik bespreek.

\section{Faktor I: Stabiliteit}

Faktor I het substansiële ladings op ses keuringskriteria, naamlik:

Nr 3 huwelikstatus

0,654

$\mathrm{Nr} 13$ besit van telefoon by woonadres $\quad 0,636$

Nr 19 gebied woonagtig $\quad 0,631$

$\mathrm{Nr} 4$ aantal afhanklikes $\quad 0,591$

Nr 17 geslag $\quad 0,548$

$\mathrm{Nr} 2$ taal 0,521

Die eerste vier keuringskriteria (Nrs 3, 13, 19 en 4), te wete huwelikstatus, besit van telefoon by woonadres, gebied woonagtig en aantal afhanklikes dui op die STABILITEIT van die kliënt. Kriteria, geslag $(\mathrm{Nr}$ 17) en taal $(\mathrm{Nr} 22)$ is 'n eienaardige kombinasie saam met die eersgenoemde vier kriteria. Omdat die cerste vier kriteria so hoog beduidend laai, word faktor I as STABILITEIT geidentifiseer.

\section{Faktor II: Transaksieverkenning}

Die tweede faktor by blankes het 'n substansiële lading op drie van die 22 keuringskriteria:

$\mathrm{Nr} 15$ afbetalingstermyn $\quad 0,734$

$\mathrm{Nr} 8$ afbetalingstussenposes $\quad 0,699$

$\mathrm{Nr} 7$ ouderdom van artikel $\quad 0,520$

Soos by kleurlinge en Indiërs is Nrs 15, 8 en 7 ook by blankes geidentifiseer as noodsaaklike transaksieverkenningsinligting. Faktor II word dus as 'n TRANSAKSIEVERKENNINGSFAKTOR geidentifiseer.

\section{Faktor III: Standvastigheid}

Faktor III laai substansieel op drie van die 22 keuringskriteria. Die kriteria is soos volg:

$\mathrm{Nr} 11$ bestaande of nuwe kliënt $\quad 0,654$

$\mathrm{Nr} 12$ besit van vaste eiendom $\quad 0,634$

$\mathrm{Nr} 10$ besit van bankrekening 0,624

Hierdie faktor word as STANDVASTIGHEID geïdentifiseer.

\section{Faktor IV: Finansiële- en risikogeskiedenis}

Faktor IV het 'n substansiële lading op vier van die 22 keuringskriteria. Die kriteria is die volgende:

$\mathrm{Nr} \quad 1$ bruto inkomste van kliënt $\quad 0,632$

$\mathrm{Nr} 20$ totale uitgawes van kliënt $\quad 0,578$

Nr 16 vonnisse teen kredietrekord $\quad 0,564$

$\mathrm{Nr} 9$ kredietverwysings $\quad 0,548$

Nrs 20 en 16 laai ook onderskeidelik substansieel op faktore III en $V(0,354$ en 0,365$)$ maar dui in die teenwoordigheid van Nrs 1 en 9 op die finansiële- en risikogeskiedenis van die kliënt. Faktor IV word dus as FINANSIËLE- EN RISIKOGESKIEDENIS geïdentifiseer.

\section{Faktor V: Sekuriteit}

Die laaste faktor by blankes, laai substansieel op slegs een van die 22 keuringskriteria, te wete:

$\mathrm{Nr} 2$ aanwesigheid van lewens- en/of uitkeerversekering

'n SEKURITEITSFAKTOR word hier gesuggereer, maar kan nie op grond van slegs een veranderlike as sodanig geidentifiseer word nie.

\section{Swartes}

Uit die 22 keuringskriteria is vyf faktore geïdentifiseer wat vervolgens afsonderlik in oënskou geneem word.

\section{Faktor I: Stabiliteit}

Die eerste faktor het substansiële ladings op vyf keuringskriteria, naamlik:

$\mathrm{Nr} 21$ tydperk werksaam by huidige werkgewer

$\mathrm{Nr} 9$ kredietverwysings $\quad 0,653$

$\mathrm{Nr} 5$ tydperk woonagtig by huidige adres 0,606

$\mathrm{Nr} 16$ vonnisse teen kredietrekord $\quad 0,596$

$\mathrm{Nr} 6$ beroep $\quad 0,511$

Faktor I word as STABILITEIT geidentifiseer.

\section{Faktor II: Transaksieverkenning}

Hierdie faktor het substansiële ladings op vier van die 22 keuringskriteria:

Nr 15 afbetalingstermyn $\quad 0,704$

$\mathrm{Nr} 7$ ouderdom van artikel $\quad 0,672$

$\mathrm{Nr} 8$ afbetalingstussenposes $\quad 0,671$

Nr 17 geslag

0,651

Faktor II word as 'n TRANSAKSIEVERKENNINGSFAKTOR geïdentifiseer. 


\section{Faktor III: Sekuriteit}

Faktor III laai substansieel op drie keuringskriteria. Die kriteria is die volgende:

$\mathrm{Nr} 2$ aanwesigheid van lewens- en/of uitkeerversekering

0,772

$\mathrm{Nr} 10$ besit van bankrekening

0,737

$\mathrm{Nr} 12$ besit van vaste eiendom

0,624

Faktor III word as 'n SEKURITEITSFAKTOR geïdentifiseer

\section{Faktor IV: Sosiale status}

Die vierde faktor by swartes het substansiële ladings op drie van die 22 keuringskriteria, naamlik:

$\mathrm{Nr} 13$ besit van telefoon by woonadres

0,664

$\mathrm{Nr} 19$ gebied woonagtig

0,574

$\mathrm{Nr} 22$ taal

0,515

Behalwe $\mathrm{Nr} 22$, taal, wat by swartes moontlik op etniesiteit dui, het die ander twee (nrs 13 en 19) 'n verband met die sosiale status van die kliënt. Faktor IV word geidentifiseer as SOSIALE STATUS.

\section{Faktor V: Gesinsverantwoordbaarheid}

Die laaste faktor het substansiële ladings op drie van die keuringskriteria:

$\mathrm{Nr} 4$ aantal afhanklikes $\quad 0,667$

$\mathrm{Nr} 3$ huwelikstatus $\quad 0,639$

$\mathrm{Nr} 1$ bruto inkomste van kliënt 0,556

Faktor $\mathrm{V}$ word as GESINSVERANTWOORDBAARHEID geidentifiseer.

\section{Gevolgtrekkings}

Uit die keuringskriteria van die onderhawige ondersoek is daar, met die onderskeie rassegroepe as basis, verskeie onderliggende faktore of konstrukte, met behulp van hooffaktorontleding, geidentifiseer:

- met kleurlinge as basis: vyf onderliggende faktore, naamlik transaksieverkenning, gesinsverantwoordbaarheid, finansiële- en risikogeskiedenis, sekuriteit en patriotisme;

- met Indiërs as basis: ses onderliggende faktore, naamlik transaksieverkenning, gesinsverantwoordbaarheid, risikogeskiedenis, sekuriteit, standvastigheid en stabiliteit;

- met blankes as basis: vyf onderliggende faktore, naamlik transaksieverkenning, finansiële- en risikogeskiedenis, sekuriteit, stabiliteit en standvastigheid;

- met swartes as basis: vyf onderliggende faktore, naamlik transaksieverkenning, gesinsverantwoordbaarheid, sekuriteit, sosiale status en stabiliteit.

Daar dien op gelet te word dat hoewel aan sommige van die geîdentifiseerde faktore by die verskillende rassegroepe dieselfde name toegeken is, dit nie impliseer dat die gelyknamige faktore statisties dieselfde is nie. Ten einde vas te stel of die faktorstrukture met betrekking tot die verskillende rassegroepe verskil, behoort 'n intergroepfaktorontleding gedoen te word.

\section{Summary}

In this study the authors attempt to identify underlying factors from various evaluation criteria (as observed by bank managers) in considering the granting of credit in consumer banking with regard to the various race groups of the Republic of South Africa. The study is limited to commercial and general banks, since these are the largest 'suppliers' of consumer credit in the form of instalment credit (hire purchase) and leasing transactions. The investigation includes coloureds, Indians, whites, and blacks.

The sample consists of 510 managers from the consumer division of general and commercial banks distributed across the Republic of South Africa. With the aid of principal factor analysis six underlying factors were identified with respect to Indians, whereas five underlying factors were identified respectively with regard to coloureds, whites, and blacks. The factors that were identified with respect to the various race groups were the following:

(a) Coloureds: Type of transaction, family responsibility, financial risk history, security, and patriotism.

(b) Indians: Type of transaction, family responsibility, stability, risk history, security, and stability.

(c) Whites: Stability, type of transaction, steadfastness, financial risk history, and security.

(d) Blacks: Stability, type of transaction, security, social status, and family responsibility.

\section{Nota}

1. Vir doeleindes van hierdie ondersoek word die wetlike verskanste kategoriee soos in die Bevolkingsregistrasiewet van 1950 vervat, gebruik. Die woord rassegroep sal deurgaans in hierdie ondersoek gebruik word wanneer na kleurlinge, Indiërs, blankes en swartes verwys word.

\section{Verwysings}

Beckman, T.N. \& Bartels, R. 1955. Credits and Collections in Theory and Practice. 6th Edition. McGraw-Hill Book Company, INC.

Boggess, W.P. 1967. Screen-test your credit risks. Harv. Bus. Rev., vol.45, $113-112$.

Cole, R.H. 1982. Consumer and commercial Credit Management. Homewood Illinois: Richard D Irvin, INC.

Dickson, G.C.A. 1981. A comparison of attitudes towards risk among business managers. J. Occup. Psychol., vol.54, September 1981, 157-164.

Eisenbeis, R.A. 1980. Selection and Disclosure of Reasons for Adverse Action in Credit-Granting Systems. Fed. Reserve Bull., vol. 66, September 1980, 727-735.

Grablowsky, B.J. \& Talley, W.K. 1981. Probit and discriminant functions for classifying credit applications: a comparison. $J$. Econ. Bus., vol.33, (3) 254-261.

Grayson, C.J. 1960. Decisions under uncertainty: Drilling decisions by oil and gas operators. Div. Res. Harv. Bus. Sch., Boston.

Handa, J. 1977. Risk, probabilities and a new theory of cardinal utility. J. Pol. Econ., 97-122.

Kaiser, H. 1960. The application of electronic computers to factor analysis. Educ. Psychol. Measurement, vol.20, 141-151.

Karmarker, U.S. 1978. Subjectively weighted utility: A description extension of the expected utility model. Organ. Behav. Hum. Performance, $61-72$.

Pinches, G.E. \& Mingo, K.A. 1973. A Multivariate Analysis of Industrial Bond Ratings. J. Finance, vol.28, (1), March 1973, $1-18$.

Rothenberg, D. 1980. Predicting the Status of your loan . . Three years from now. J. Commer. Bank Lending, April 1980, $28-41$.

Sexton, (jun) D.E. 1977. Determining Good and Bad Credit Risks among High- and Low-Income Families. J. Bus., vol.50, $236-239$.

Sinkey, (jun) J.F. 1983. Commercial Bank Financial Management. New York: McMillan Publishing Co, INC.

Sheth, J. \& Tigert, D.J. 1970. Factor analysis in Marketing. American Marketing Association Workshop on Multi-variate Methods. Chicago; Illinois.

Stanhouse, B. \& Sherman, L. 1979. A note on information in loan evaluation process. J. Finance, vol.34, (S). December 1979, $1263-1269$

Spetzler, C.S. 1968. Development of a corporate risk policy for capital investment decisions. IEEE Trans. Syst., Sci. Cybern., SSC, $279-300$.

Suid-Afrikaanse Reserwebank, 1980. Kwartaalblad, Maart 1980, $\mathrm{Nr} 143$.

Suid-Afrikaanse Reserwebank, 1985. Kwartaalblad, Maart 1985, Nr 155.

Tabor, J.S. \& Bowers, J.S. 1977. Factors Determining Credit 
Worthiness of Low Income Consumers. J. Consum Affairs, vol.11, (2), 43-51.

Van Rensburg, W.P.J. 1983. Die voorspelling van Kredietrisiko met behulp van Biografiese veranderlikes, ongepubliseerde M.Comm-verhandeling, Universiteit van Suid-Afkrika, Pretoria, Maart 1983.

Wantland, C.A. 1977. How a Banker Evaluates a Credit Risk,
Credit Finan. Manage., vol.77, September 1977, 16-17.

Wingington, J.C. 1980. A note on the comparison of logit and discriminant models of consumer credit behaviour, J. Financ. Quan. Anal., vol.15 (3), September 1980, 757-766.

Zimmer, 1. 1981. A comparison of the Prediction Accuracy of Loan Officers and their Linear-Additive Models, Organ. Behav. Hum. Performance, vol.27, 69-74. 